Supplement of Nat. Hazards Earth Syst. Sci., 16, 311-331, 2016

http://www.nat-hazards-earth-syst-sci.net/16/311/2016/

doi:10.5194/nhess-16-311-2016-supplement

(C) Author(s) 2016. CC Attribution 3.0 License.

(c) (1)

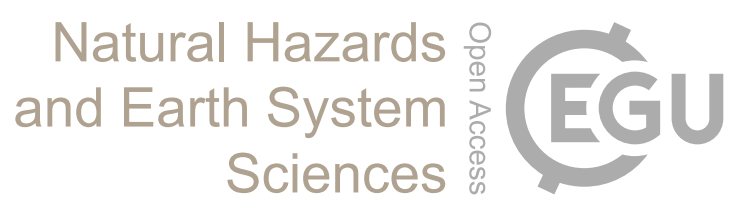

Supplement of

\title{
Assessment of physical vulnerability of buildings and analysis of landslide risk at the municipal scale: application to the Loures municipality, Portugal
}

\section{Guillard-Gonçalves et al.}

Correspondence to: C. Guillard-Gonçalves (cguillard@ campus.ul.pt)

The copyright of individual parts of the supplement might differ from the CC-BY 3.0 licence. 


\section{Supplement:}

Supplement 1. Matrix of the experts questionnaire

\begin{tabular}{|c|c|c|c|c|c|c|c|c|c|}
\hline & \multicolumn{5}{|c|}{$\begin{array}{c}\text { Landslide body } \\
\text { (rotational slide): } \\
\text { Depth of the slip surface (m) }\end{array}$} & \multicolumn{4}{|c|}{$\begin{array}{l}\text { Landslide foot: } \\
\text { Height of affected material (m) }\end{array}$} \\
\hline & 1 & 3 & 5 & 10 & 20 & 0.5 & 1 & 3 & 5 \\
\hline \multicolumn{10}{|l|}{ STB1 } \\
\hline \multicolumn{10}{|l|}{ STB2 } \\
\hline \multicolumn{10}{|l|}{ STB3 } \\
\hline STB4 & & & & & & & & & \\
\hline
\end{tabular}

Note: complete with a potential damage between 1 (negligible damage) and 5 (very severe damage).

\begin{tabular}{cl}
\hline Structural building type & Structural elements and construction material \\
\hline SBT1 & Wood or metal (light structures) \\
SBT2 & Adobe, rummed earth or loose stone walls \\
SBT3 & Brick or stone masonry walls \\
SBT4 & Masonry walls confined with reinforced concrete \\
\hline
\end{tabular}

\section{Potential} damage class

Damage level on buildings (based on Alexander, 1986; AGS, 2000; Tinti et al., 2011;

1: Negligible damage

2: Slight damage

3: Significant damage

4: Severe damage

5: Very severe damage Garcia 2012)

No significant damage - slight accumulation of material originating aesthetic damages (dirt, chipping paint, etc.)

No structural damage - minor repairable damage: chipping of plaster, slight cracks, damage to doors and windows

No structural damage - major damage requiring complex repair: displacement or partial collapse of walls or panels without compromising structural integrity, highly developed cracks. Evacuation required

Structural damage that can affect the stability of the building: out-of-plane failure or collapse of masonry, partial collapse of floors, severe cracking or collapse of sections of structure due to settlement. Immediate evacuation; demolition of the element may be required.

Heavy damage seriously compromising the structural integrity: partial or total collapse of the building. Imperative and immediate evacuation and complete demolition. 